\title{
Digital financial inclusion and fiscal solvency in Uganda's local governments: A review of regulation mediation
}

\author{
Paul Onyango-Delewaa ${ }^{*}$; Isaac Nabeta Nkote $^{2}$
}

1) Department of Accounting and Finance, Faculty of Business and Development Studies, Gulu University, Gulu, Uganda

${ }^{2)}$ Faculty of Commerce, Makerere University Business School, Makerere University, Kampala, Uganda

*To whom correspondence should be addressed. Email: ponydel2005@gmail.com

\begin{tabular}{|l|l|l|l|l|}
\hline DOI: & Received: & Revised: & Accepted: & Published: \\
10.22437/ppd.v8i6.8861 & 12.03 .2020 & 17.03 .2020 & 03.08 .2020 & 01.02 .2021 \\
\hline
\end{tabular}

\begin{abstract}
Fiscal solvency has become a popular phenomenon in numerous decentralizing countries in recent years. The ability to mobilize adequate revenue to fund expenditure in a given budget period, and provide public goods and services, makes fiscal solvency very pertinent, especially in local government. However, policy, practice, and research, claim that most local entities, both in the developed and developing world, rarely achieve required fiscal solvency standards. While no clear explanation of the problem abounds, digital financial inclusion dominates the ongoing debate. Besides, regulation is also considered a very crucial factor for fiscal solvency. This study examines the probable mediation effect regulation has on the digital financial inclusion-fiscal solvency relationship in local governments in Uganda, East Africa. Based on a cross-sectional research design, data were collected from 21 districts, nine municipalities, and many subcounties in the country's post-conflict northern regions. The data were then subjected to structural equation modeling analysis. Its findings reveal that digital financial inclusion explains changes in fiscal solvency in surveyed local governments. Moreover, regulation has an indirect influence on the digital financial inclusion-fiscal solvency formation. Findings implications to practice and theory are discussed, and future research direction is provided.
\end{abstract}

Keywords: Digital financial, Fiscal solvency, Local government

JEL Classification: $\mathrm{H} 72$, G38, O16, O33

\section{INTRODUCTION}

It is quite recent that government entities' fiscal solvency started to receive attention from policy, practice, and research. Previously restricted to fiscal federalism specialist domains, lack of fiscal solvency has over time undermined resource management in public units unnoticed (Sepulveda \& Martinez-Vazquez, 2011; Thornton, 2007). The malaise, exacerbated by corruption and other malpractices, dominates local government financial and budgetary structures, especially in newly decentralizing countries of the developing world (Arzaghi \& Henderson, 2005; Lessman, 2012). Sub-Saharan African 
region local entities, Uganda inclusive, have been particularly vulnerable, given their relatively weak managerial capabilities and non-punitive budgetary regulations (Gauthier, 2001; Talvi \& Végh, 2005).

Gauthier (2001) and Lessman (2012) associate the fiscal health of government (especially local governments) with fiscal solvency. Public fiscal health is a threedimensional phenomenon: fiscal position, fiscal condition, and economic condition. An entity's fiscal position relates to the state of its assets and liabilities. These require continuous cash flows or the ability for conversion to cash in the short-term (liquidity) (Lessman, 2012).

Government fiscal condition is about its aptitude to meet financial obligations to, say, suppliers, creditors, and lenders as they fall due. Often referred to as fiscal solvency, state when the entity can service its financial obligations to concerned constituents now and in the future (Gauthier, 2001; Thornton, 2007). Previous studies (e.g., Alesina, Baqir \& Easterly, 1999) have long captured economic conditions to embrace the entire government fiscal health as a whole. Specifically, it is the entity's potential to meet financial obligations and service delivery commitments within the set budgetary framework (Alesina, Baqir \& Easterly, 1999; Arzaghi \& Henderson, 2005).

Fiscal solvency, especially in fiscal federalism structures, can be clearly understood from four contexts; cash, budgetary, long-run, and service-level solvency (Gauthier, 2001; Reinikka \& Svensson, 2006). Cash-related solvency is the entity's ability to generate adequate cash amounts over, say, 30-60 days to service its recurrent bills. Budgetary solvency can mobilize enough revenue over the normal budgetary timespan to finance expenditure and yet without entering into debt. Long-run solvency is a situation when a public entity is sustainably able to meet all its administrative and other costs over a long time (Gauthier, 2001).

Service-level solvency relates to that component of financial health when the government can render services at the local communities' level and quality satisfactorily. The services may include education, health, road networks, water, and sanitation (Gauthier, 2001; Talvi \& Végh, 2005).

Conventional empirical evidence (e.g., Alesina, Baqir \& Easterly, 1999; Reinikka \& Svensson, 2006; Thornton, 2007) provides that majority localities often violate budgetary and service delivery mandates relative to cash and long-run solvency dimensions. Several scholars (Morawczynski, 2009; Salvador, Sherry \& Urrutia, 2005; Yakub, Bello \& Adenuga, 2013) assert that dynamics largely cause violation of budgetary and service delivery obligations in local agencies in digital financial inclusion.

Electronic or e-financial mechanisms commonly exclude local communities incapacitating them from paying local taxes required for budgetary purposes. Resultant constrained budgets create service delivery setbacks (Salvador, Sherry \& Urrutia, 2005; Yakub, Bello \& Adenuga, 2013).

Besides, locality budgetary and service delivery challenges are also closely associated with fiscal solvency regulation (de Mello, 2000; Prud'homme, 1995). Fiscal federalism in general and fiscal solvency is surrounded by a series of laws and statutes meant to enhance efficiency and transparency. Prud'homme (1995) argues that, given that such regulation is created at the center, it rarely captures local entities' operational realities. It exposes most agencies to budgetary and service delivery risks (Otenyo \& Lind, 2004; Prud'homme, 1995).

This research is a close analysis of the digital financial inclusion-fiscal solvency relationship in African-based local governments. Specifically, regulation, a factor to which previous studies have paid very little attention, is investigated as a possible 
mediator in the relationship. In Uganda, local government fiscal solvency concerns, an East African country applauded for its proficient fiscal federalism mechanism, are used as a proxy. The focus is on local entities' operations located in the country's post-conflict northern regions of West Nile, Northern (Acholi and Lango areas), and Karamoja.

\section{LITERATURE REVIEW AND HYPOTHESES}

\section{Fiscal solvency}

In local government, fiscal solvency is a fiscal condition that unveils an entity's ability to meet its financial obligations to suppliers, creditors, and lenders as they fall due (Gauthier, 2001; Thornton, 2007). Local entities are particularly obliged to meet their service mandate to the communities now and in the future.

Incidentally, effectively meeting that mandate on a sustainable basis is a function of multiple factors. Common factors are largely environmental, organizational, and financial (Alesina, Baqir \& Easterly, 1999; Thornton, 2007).

According to Gauthier (2001) and Talvi \& Végh (2005), the entity environment encompasses community needs and resource structure, political culture, and intergovernmental constraints. The entity must appreciate its community population age, income-generating capacity, and employment potential from the community needs and resource structure context. Such factors are critical for planning and budgeting necessary in fulfilling service delivery obligations (Alesina, Baqir \& Easterly, 1999; Talvi \& Végh, 2005).

The locality also needs to understand the partisan political formation under which it is operating. Politics significantly influence resource allocation and government program management (Arzaghi \& Henderson, 2005; Gauthier, 2001). Moreover, various local governments fail to realize expected fiscal solvency criteria due to constraints rooted in inter-governmental fiscal relations. These encompass the management of intergovernmental transfers (grants) and budgetary regulations (Alesina, Baqir \& Easterly, 1999; Reinikka \& Svensson, 2006).

At the organizational level, the administrative machinery employed and staff technical capacity to make effective fiscal decisions seriously impact entity fiscal solvency. Sepulveda \& Martinez-Vazquez (2011) noted that rampant corruption and bureaucratic practices surrounding several local governments, especially in Africa, are associated with organizational impediments. In most jurisdictions of Africa, several local entity administrators and departmental heads lack the technical competence required to constitute and interpret a balanced budget (Lessman, 2012; Sepulveda \& MartinezVazquez, 2011).

Financial factors that influence local authorities relate to revenue mobilization (growth and source diversity), expenditure (setting priorities, meeting mandates, and expenditure performance), and program management (maintenance and capital outlay efficiency). These factors drive fiscal solvency (Alesina, Baqir \& Easterly, 1999; Talvi \& Végh, 2005).

Fiscal efficiency theory (King, 1984; Musgrave \& Musgrave, 1980; Oates, 1972) is the dominant theoretical underpinning that attempts to explain local entity fiscal condition. The theory holds that local taxes embrace several operational features capable of financially supporting decentralized public expenditure systems if managed well. For instance, local tax bases should be neither very mobile nor unevenly distributed amongst the various local jurisdictions (Musgrave \& Musgrave, 1980; Oates, 1972).

In dynamic environments, say those occasioned by rapid technological mobility, taxpayers may relocate the income activities or tax sources from high to low areas. Such 
society re-location will affect total revenue collected and limit entity capacity to adjust tax rates accordingly. Prompt tax adjustments made to suit budget solvency at a particular period is critical for ultimate entity budget performance (King, 1984; Musgrave \& Musgrave, 1980). The entity's environmental-organizational-financial factors triangulation outlined above seriously affects its budgetary and service-level solvency.

In Uganda, most local governments, especially those emerging from civil conflict, frequently fall victim to the fiscal solvency trap. Quite often, less local revenue is collected than what is budgeted for smaller amounts released by the central government in grants. Coupled with constrained donor aid support, it is common that their budgets rarely perform (Reinikka \& Svensson, 2006).

Budgets in local governments in the West Nile, Northern, and Karamoja regions are very prone to fiscal solvency setbacks. As communities struggle to cope-up economically with those of other regions in the country, budgetary legislation requires that they must also operate functioning budgets (Reinikka \& Svensson, 2006). Ultimately, non-performing budgets in the regions have inevitably affected the quality of service delivery. Thus, the regions' level of education, health services, road networks, and water and sanitation remains largely below average (Talvi \& Végh, 2005).

\section{Digital financial inclusion}

Large sections of local community populations save, send money, and even access loans through financial systems that are neither supervised nor regulated. This practice, typical of the developing world and currently widespread in Sub-Saharan Africa, constitutes the so-called shadow or informal cash-based economy (Morawczynski, 2009; Schneider \& Enste, 2000).

Digital financial inclusion research (Gilbert, 2005; Madon, 2005; Salvador, Sherry \& Urrutia, 2005) reveals that such communities comprise the biggest percentage, at least $70 \%$, of the entire population of respective countries. Their inclusion in the formal digital financial sector would lead to national economic growth and significantly reduce poverty (Madon, 2005; Salvador et al., 2005).

Commonly defined as digital access to and applying financial services by underserved or entirely excluded populations (Morawczynski, 2009; Phillips \& Ilcan, 2007; Yakub, Bello \& Adenuga, 2013), digital financial inclusion mechanisms only require suitable adjustments to benefit the affected groups.

Phillips \& Ilcan (2007) suggest that tailoring the mechanisms to customer needs, responsible delivery, affordability, and cost-effectiveness to service providers would significantly enhance that objective's attainment.

The actor-network theory (Green, Hull, McMeekin \& Walsh, 1999; Hanseth, Monteiro \& Hatling, 1996) suggests a combination of agency and structure for effective digital financial inclusion. Besides, this leading theoretical direction asserts that neither the agency nor the structure should operate independently of the other. In practice, society consists of human and non-human players who foster digital financial activity (Hanseth, Monteiro \& Hatling, 1996). Conventional agency-structure configurations in Africa are driven by a transaction platform, retail agents, and some devices (Madon, 2005; Morawczynski, 2009; Schneider \& Enste, 2000).

\section{Transaction platform}

The platform makes it possible for customers to use the device to transact; that is, make and receive payments, transfer, and store money electronically with financial or non-financial but authorized institutions (Morawczynski, 2009; Olayinka, 2015; Yakub, 
Bello \& Adenuga, 2013). Moreover, it can accommodate small and unpredictable cash flows affordable by most poverty-stricken and village-resident populations.

Data platforms create through continuous customer interaction enable financial institutions to develop pro-poor easy-to-repay products. Furthermore, most transactional platforms engaged are acclaimed for promoting easy accessibility to other financial products such as loans, insurance, interest-based savings, and investments (Morawczynski, 2009; Olayinka, 2015).

In general terms, transactional platforms have generated unprecedented financial service demand that has impacted most local populations' income capacities. Notable examples in Africa include Tigo Family Care insurance (Ghana), Commercial Bank of Africa-oriented M-Shwari consumer loans and M-Pesa (Kenya), Nigeria's FirstMonie, and MTN and Airtel (Uganda).

Recently, Uganda-based MTN and Airtel e-financial institutions launched almost similar products to benefit the largely rural-based poor. The post-conflict communities are an active consumer group of the services offered (Morawczynski, 2009; Olayinka, 2015). The services have not only improved their livelihoods, but the interaction has boosted local business activity. Depending on local entity capacity to mobilize local taxes, enhanced business leverage significantly influences societal contribution to budgeting and service delivery (Olayinka, 2015; Salvador et al., 2005). The attribute transactional platform thus substantiates the proposal of the following hypothesis:

H1: Digital transaction platform relates positively to fiscal solvency.

\section{Retail agents}

Retail agents are registered and regulated individuals or institutions that operate digital devices to help customers convert cash to electronically-stored value or the other way around. Yakub et al. (2013) identify the agents with facilities linked to communication infrastructure capable of transmitting and receiving customer monetary transaction details. Consistent with the actor-network theory (Green, Hull, McMeekin \& Walsh, 1999; Hanseth, Monteiro \& Hatling, 1996), agents are the actors whose intervention in the platform-device-customer connections renders the entire digital financial inclusion machine very effective.

As a contribution to local entity fiscal solvency, retail agents expose local community digital financial facility users (taxpayers and service recipients) to business efficiency that ultimately strengthens their earning power (Phillips \& Ilcan, 2007). However, where regulation is weak, retail agents may cause serious risks to both service providers and customers. According to Madon (2005), service providers are vulnerable to agent-oriented operational and even cyber-related risks such as fraud, poor cash management, inefficient data management, and frequent errors. These setbacks hamper customer participation and frustrate their business activity (Madon, 2005; Schneider \& Enste, 2000).

Besides, given their limited financial management aptitude, most agents can notably comply with anti-money laundering regulations and customer due diligence requirements. Empirical evidence (Morawczynski, 2009; Salvador, Sherry \& Urrutia, 2005) further indicates that some agents over-charge customers or involve abusive language, which eventually leads to violation of personal data confidentiality.

In sum, both the positive and negative contributions retail agents make to the digital financial inclusion-customer (community) equation have a surmountable bearing on the local government's fiscal solvency drive. Post-conflict northern Uganda local communities and their local governments are in no way immune to the MTN-Airtel retail agents' machinations. Like their counterparts in other parts of Africa, they need the 
services to be part of the global digital financial society and are forced to bear with its dynamics (Olayinka, 2015; Yakub, Bello \& Adenuga, 2013). The retail agents construct leads to the following prediction:

H2: Retail agents' activities relate positively to fiscal solvency.

\section{Devices}

In Sub-Saharan Africa, the mobile phone dominates the digital financial device structure (Morawczynski, 2009; Salvador et al., 2005). All homes have mobile phones, held for both communication and money transfer purposes. In most jurisdictions, all mobile phone devices are registered. Registration of phone owners is undertaken to facilitate personal holder security, curb phone theft, and, most importantly, check cyberrelated financial transfer crimes (Morawczynski, 2009; Olayinka, 2015).

Some scholars (Madon, 2005; Phillips \& Ilcan, 2007; Schneider \& Enste, 2000) observe that phone owners and their devices' registration is a deliberate government strategic move. Essentially, registration reveals people's incomes, spending habits, partisan political position, and their stand on the quality of public goods and services offered. To achieve this multi-dimensional strategic goal, the state often secretly institutes a digital communication monitoring system (phone tapping) (Phillips \& Ilcan, 2007; Schneider \& Enste, 2000).

Local government officials in Uganda and the communities they serve, post-conflict northern regions inclusive, predominantly employ the mobile phone as the digital financial inclusion device. Thus, the device is considered instrumental in enhancing fiscal solvency in such entities (Morawczynski, 2009). In that consideration, we put forward the hypothesis:

H3: Device application relates positively with fiscal solvency.

\section{Regulation}

Fiscal federalism entails the center transferring some of its fiscal administrative and management powers to sub-national entities (de Mello, 2000; Prud'homme, 1995). Ideally, the entities are given the constitution or some specific law mandate to raise local revenue (taxes) and carry out spending activities but strictly within a clearly-set regulatory framework.

Raising revenue and spending is a function of two critical engagements, budgeting, and service delivery (Prud'homme, 1995; Reinnikka \& Svensson, 2004). Since fiscal federalism, the bedrock of locality budgeting, is undertaken within some pre-conceived legal criteria, and it is therefore of little doubt that fiscal solvency is under regulatory oversight. Otenyo \& Lind (2004) noted that regulation enhances budgetary discipline and promotes quality service delivery, especially in Africa's resource-constrained local entities. Budgetary discipline enables the entity to remain budget solvent for a long time (de Mello, 2000; Otenyo \& Lind, 2004).

The sudden emergence of digital financial inclusion culture in most developing countries and particularly in Sub-Saharan Africa has caught most fiscal, regulatory mechanisms unawares (Madon, 2005; Olayinka, 2015; Yakub, Bello \& Adenuga, 2013). Few national constitutions and their offshoot sub-national entity laws capture the volatile operational elements of e-financial systems. Thus there is a high incidence of transaction platform-retail agent-device service violations with impunity, especially from the local government fiscal solvency context (Morawczynski, 2009; Olayinka, 2015).

In Uganda, the national constitution (1995), the Budget Act (2001), and the Local Government Act (1997 amended) constitute the regulatory framework governing fiscal activities in its local governments (Otenyo \& Lind 2004; Reinnikka \& Svensson 2004). 
However, this legal structure is yet to fully-appreciate the digital financial inclusion-fiscal solvency linkages in local entities. Most of the governing guidelines are embedded in the financial services statutes, quite different from, say, those in the Local Government Act (1997 amended) (Reinnikka \& Svensson 2004). From the preceding analysis, it also proposed that:

H4: Regulation mediates the relationship between digital financial inclusion and fiscal solvency.

\section{METHODS}

\section{Sample}

Data were collected from randomly and purposively-selected (Baruch \& Holton 2008; Creswell 2003) 21 districts, nine municipalities, and some sub-counties in postconflict northern and Karamoja regions Uganda. Local entities in the selected regions are susceptible to budget solvency challenges but are big consumers of the prestigious digital financial services (Morawczynski, 2009; Otenyo \& Lind, 2004; Reinikka \& Svensson, 2006). A total of 250 structured questionnaires were distributed to various administrators and department heads, while civic leaders were interviewed.

The questionnaire contained statement items regarding the study variables and their constructs built on a 5-point Likert scale. The scale was anchored on a "Strongly Disagree-Strongly Agree" configuration (Baruch \& Holton, 2008; Cohen, Cohen, West $\&$ Aiken, 2003). The response rate from the unit of analysis, a district, the context was $100 \%$ given that at least a questionnaire was received from each locality. Overall, 240 questionnaires were received back, denoting a $96 \%$ unit of inquiry response rate. However, only 223 of them were taken on for hypothesis testing due to missing data and response inconsistence setbacks (Cohen et al., 2003; Creswell, 2003).

\section{Measures}

Fiscal solvency: The constructs operationalized fiscal solvency: budgetary activity and service-level operations (Arzaghi \& Henderson, 2005; Thornton, 2007). The budgetary activity was measured by scales adapted and modified from Thornton (2007) $(\alpha=0.844)$. Sample statements: "This entity always balances its budgets."; "Local revenue is often collected as budgeted for." The service-level operations construct was assessed by modified versions of scales employed by Arzaghi \& Henderson (2005) $(\alpha=0.903)$. Sample statement: "The type of public goods and services offered by the entity is of quite good quality."

Digital financial inclusion: The transactional platform, retail agents, and devices are notable ingredients of digital financial inclusion (Morawczynski, 2009; Yakub, Bello \& Adenuga, 2013). Transactional platform concerns were examined using tailored scales in Morawczynski (2009) ( $\alpha=0.826)$. Sample statements: "The platform is responsible for frequent network disruptions."; "It cannot be easily modified to suit local service consumption circumstances." The retail agents' role was assessed based on guidelines in Yakub, Bello \& Adenuga (2013) ( $\alpha=0.877)$. Sample statements: "The agents are simply money-minded and are not bothered about customers."; "Most of the agents are government spies and often violate customer confidentiality." Finally, to verify the device construct's operations, scales in Madon (2005) $(\alpha=0.894)$ were espoused. Sample statement: "Most mobile phones are too complicated to use."; "The phones cannot be easily repaired."

Regulation: The study adopted the regulation as a probable mediating factor in the digital financial inclusion-fiscal solvency relationship. The variable was measured using modified scales in de Mello (2000) and Otenyo \& Lind (2004) $(\alpha=0.914)$. Related 
sample statements: "The existing budgetary laws and regulation have been suitably tailored to address local government realities."; "The laws are easy to enforce."; "Entity administrators easily understand them."

\section{Control variables}

Participants' gender, education, position, and tenure are biographical components commonly considered very impactful to the local government's fiscal solvency management (Lessman, 2012; Talvi \& Végh, 2005). Thus, to suppress their potential influence on the study findings, we included them in the study model as control variables.

Gender was assessed dichotomously $(0=$ Female, $\mathrm{N}=93 ; 1=$ Male, $\mathrm{N}=130)$. Educational status was coded as $(1=$ Secondary Level, $\mathrm{N}=26 ; 2=$ Diploma, $\mathrm{N}=61 ; 3$ $=$ First Degree, $\mathrm{N}=97 ; 4=$ Other Qualifications, $\mathrm{N}=39$ ). Job position was coded by (1 $=\mathrm{RDC}, \mathrm{N}=25 ; 2=\mathrm{CAO}, \mathrm{N}=34 ; 3=\mathrm{LC} 5$ Chairpersons, $\mathrm{N}=26 ; 4$ = Heads of Department, $\mathrm{N}=79 ; 5=$ Councilors, $\mathrm{N}=59$ ). Tenure within the entity and serving under the current supervisor was captured to cover the range (up to $2-11$ plus) years.

Besides, we also identified and controlled one latent factor to expedite the statistical analysis required for Harman's One Factor validity testing. Simulation research (e.g., Cheung \& Lau 2008; Preacher \& Kelley 2011) recommends control for latent factors to mitigate their potential negative effects on hypothesis testing and its outcome.

\section{Data analysis}

Data analysis was carried out in four phases; first, participant biographical data were subjected to descriptive statistical analysis (Cohen et al., 2003; Creswell, 2003) to establish their status. Second, the study variables and constructs were also subjected to descriptive statistical analysis to generate their means and standard deviations. This phase also encompassed running variables and constructed inter-correlational tests and Cronbach alpha coefficients to establish instrument reliability (Baruch \& Holton 2008; Cohen et al. 2003).

Third, data were treated to multiple regression analysis to confirm their $\left(\mathrm{R}^{2}\right)$ strength and their multicollinearity status (Baruch \& Holton 2008; Cohen et al. 2003; Creswell 2003). Fourth, structural equation modeling (SEM) was tested on the data. The purpose of this test is to establish direct and indirect (mediation) effects of the various hypotheses (Barrett, 2007; Bollen, 1990; Cheung \& Lau, 2008; Preacher \& Kelley, 2011) proposed in the study.

\section{RESULTS AND DISCUSSIONS}

\section{Descriptive statistical analysis}

The results reveal that 54\% of the 223 participants are male and in the (31-39) year age bracket. Most of them (52\%) are married, educated to the level of Bachelor's degree $(22 \%)$, and have served in their respective positions for at most five years.

These results are in line with previous research (Otenyo \& Lind, 2004; Reinikka \& Svensson, 2006), which indicates that fiscal and particularly budgetary activities in Uganda's local governments are managed by fairly young and quite inexperienced male personnel. Besides, it is a workforce whose managerial and technical capacity is yet to develop (Otenyo \& Lind, 2004).

The descriptions of the research variables are given in Table 1 . The results presented in Table 1, indicate quite sizeable mean and standard deviation values. The variable and construct reliability coefficients are also fairly high $(\alpha \geq .70)$. 
Table 1. Variable means, standard deviations, reliability coefficients, and correlations

\begin{tabular}{|c|c|c|c|c|c|c|c|c|c|c|}
\hline Variable Item & $M$ & SD & 1 & 2 & 3 & 4 & 5 & 6 & 7 & 8 \\
\hline 1.Transactional Platform & 3.15 & 1.519 & .825 & & & & & & & \\
\hline 2.Retail Agents & 2.97 & 1.557 & $-.364 * *$ & .813 & & & & & & \\
\hline 3.Device & 2.92 & 1.524 & .185 & $-.390 * *$ & .786 & & & & & \\
\hline 4.Digital Financial Inclusion & 2.85 & 1.558 & .244 & .304 & $-.489 * *$ & .811 & & & & \\
\hline 5.Budgetary Activity & 3.19 & 1.528 & $.319^{*}$ & $.123^{*}$ & .270 & $-.315^{* *}$ & .798 & & & \\
\hline 6.Service-Level Operations & 2.98 & 1.517 & $.252 * *$ & $-.248 * *$ & $.136^{*}$ & .284 & $-.332 * *$ & .805 & & \\
\hline 7.Fiscal Solvency & 3.04 & 1.586 & $-.259 * *$ & $.260 * *$ & $-.112 *$ & $.194 * *$ & .267 & $-.483 * *$ & .884 & \\
\hline 8.Regulation & 3.03 & 1.499 & .304 & -.259 & .106 & $-.167 *$ & .106 & .228 & $-.296 * *$ & .856 \\
\hline
\end{tabular}

Most inter-variable/construct correlation values are quite moderate and acceptable empirically (Cohen et al. 2003; Creswell 2003). For instance, fiscal solvency exhibits a positive and significant relationship with digital financial inclusion $(r=.194, p<.01)$. It means that when digital financial inclusion improves by $19 \%$, the standard of fiscal solvency also improves to a similar magnitude. On the contrary, regulation and digital financial inclusion relate negatively but significantly $(\mathrm{r}=-.167, \mathrm{p}<.05)$. As digital financial inclusion gains ground to the extent of $17 \%$, there could be lapses in the regulation of the same level.

Moreover, regulation and fiscal solvency have a negative and significant relationship to the extent of $(\mathrm{r}=-.296, \mathrm{p}<.01)$. As laws and regulations become stringent to a magnitude of $30 \%$, fiscal solvency standards also deteriorate by the same percentage. Finally, budgetary activity is associated with retail agent operations to a positive and significant level of $(r=.123, \mathrm{p}<.05)$ interpreted along similar lines.

\section{Multiple regression and structural equation modeling}

Both regression and SEM analytical output are given in Table 2.

Table 2. Multiple regression and Structural Equation Modeling

\begin{tabular}{|c|c|c|c|c|c|c|c|c|}
\hline \multirow[t]{2}{*}{ HYP } & \multirow[t]{2}{*}{ Model } & \multicolumn{2}{|c|}{$\begin{array}{l}\text { Unstandardized } \\
\text { Coefficients }\end{array}$} & \multirow{2}{*}{$\begin{array}{c}\text { Standardized } \\
\text { Coefficients } \\
\beta\end{array}$} & \multirow[t]{2}{*}{ t-value } & \multirow[t]{2}{*}{ Sig. } & \multicolumn{2}{|c|}{$\begin{array}{c}\text { Collinearity } \\
\text { Statistics }\end{array}$} \\
\hline & & $\beta$ & SE & & & & TV & VIF \\
\hline \multirow[t]{6}{*}{ RGN } & Constant & 3.775 & 1.408 & & 2.680 & $* *$ & & \\
\hline & Transactional Platform & -.611 & .195 & -.556 & -3.133 & $*$ & .413 & 2.423 \\
\hline & Retail Agents & .508 & .180 & .508 & 2.825 & $*$ & .401 & 2.484 \\
\hline & Device & .581 & .183 & .398 & .728 & $* *$ & .713 & 1.403 \\
\hline & $\mathrm{R}^{2}$ & & & .961 & & & & \\
\hline & Adjusted $\mathrm{R}^{2}$ & & & .922 & & & & \\
\hline SEM & Direct Effects & & & & & & & \\
\hline H1 & Transactional Platform --> Fiscal Solvency & & & -.195 & -2.835 & $* *$ & & \\
\hline $\mathrm{H} 2$ & ----> Fiscal Solvency & & & .372 & 2.114 & $* *$ & & \\
\hline \multirow[t]{2}{*}{$\mathrm{H} 3$} & ----> Fiscal Solvency & & & .249 & 2.762 & $*$ & & \\
\hline & Indirect (Mediation) Effect & & & & & & & \\
\hline \multirow[t]{2}{*}{$\mathrm{H} 4$} & 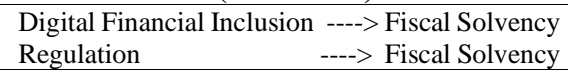 & & & $\begin{array}{l}.266 \\
.158\end{array}$ & $\begin{array}{l}2.407 \\
4.656 \\
\end{array}$ & $\begin{array}{l}* \\
* * \\
* *\end{array}$ & & \\
\hline & Bootstrap: 95\% Bias-Corrected CIs: [.016; .093 & & & & & & & \\
\hline
\end{tabular}

Variable direct effects were verified at two levels; multiple regression analysis levels and SEM level. From the multiple regressional contexts, results (Table 2), indicate a negative but significant transactional platform-fiscal solvency relationship $(\beta=-.556$; $t-$ value=-3.133). These results suggest that the study data do not support Hypothesis 1 in which a positive relationship had been predicted. In Hypothesis 2, it had been proposed 
that retail agents' activities relate positively to fiscal solvency. Data support that hypothesis $(\beta=.508 ; \mathrm{t}$-value=2.825). Hypothesis 3 which stated that device and fiscal solvency hold a positive relationship, also secured data support as per the regression output $(\beta=.398$; $t$-value $=.728)$.

The regression results were founded on a regression model whose adjusted $\mathrm{R}^{2}$ value is quite robust (Adj. $\mathrm{R}^{2}=.922$ ). Moreover, variable multicollinearity indicators meet the empirical standards; tolerance values $(\mathrm{TV} \leq 1.00)$ and variance inflation factors $(\mathrm{VIF} \leq$ 10.00). The results indicate that the study variables hold no collinearity identities (Cohen et al. 2003; Creswell 2003).

Firstly, structural equation modeling enabled the assessment of the common methods variance threat to the data set. Initially, data were subjected to exploratory factor analysis (EFA) for screening and then to confirmatory factor analysis (CFA) for manipulation. Barrett (2000) \& Bollen (1990) recommend creating two models; a multifactor measurement model and Harman's one-factor model, whose goodness-of-fit indices can be compared to establish the presence of the common methods variance threat ably.

The goodness-of fit indices for a six-factor (transactional platform, retail agents activities, device, budgetary activity, service-level operations, and regulation) model; namely, $(\chi 2=7.521 ; \mathrm{df}=9 ; \chi 2 / \mathrm{df}=0.836$; IFI $=0.970$; TLI $=0.985 ;$ CFI $=0.977$; RMSEA $=0.023$; L.471, H.622) compared much better than those of the Harman's latent-based single model $(\chi 2=12.803 ; \mathrm{df}=14 ; \chi 2 / \mathrm{df}=0.915 ; \mathrm{IFI}=0.808 ; \mathrm{TLI}=0.905$; $\mathrm{CFI}=0.844 ;$ RMSEA $=0.219 ;$ L.098, H.123).

The previous results of the two sets of goodness-of-fit indices signify the absence of common methods variance threat to the data (Barrett, 2000; Bollen, 1990; Preacher \& Kelley, 2011). This finding is also a strong indication that there was both construct and discriminant validity of the instrument that was employed in the data collection process (Barrett, 2000; Preacher \& Kelley, 2011).

Structural equation modeling results further confirm inter-variable direct effects initially generated in the multiple regression model. Accordingly, transactional platform-fiscal solvency $(\beta=-.195, t$-value $=2.835, p<.01)$; retail agents-fiscal solvency $(\beta=.372, \mathrm{t}$-value $=2.114, \mathrm{p}<.01)$; device-fiscal solvency $(\beta=.249, \mathrm{t}$-value $=2.762, \mathrm{p}<$ .05). Data supported both Hypotheses 2 and 3 but did not support Hypothesis 1.

It had been predicted in Hypothesis 4 that: regulation mediates the relationship between digital financial inclusion and fiscal solvency. Consistent with previous empirical literature (Kenny, 2008; Shrout \& Bolger, 2002), mediation results (Table 2) $[\beta=.266, \mathrm{p}<0.05 ; \beta=.158, \mathrm{p}<0.01]$, indicate that Hypothesis 4 secured supported from the data.

Two thousand five hundred mini-samples were created and subjected to structural equation modeling-based bootstrapping mediation testing. Bootstrapping generates two confidence intervals (lower and upper) that facilitate the determination of mediation presence. Mediation is considered existent and significant if no zero value lies in the confidence interval range (Preacher \& Kelley, 2011). The 10\% effect size and 95\% biascorrected zero-less confidence interval (CI): [.016; .093], confirms that Hypothesis 4 still secures support from the data (Cheung \& Lau, 2008; Preacher \& Kelley, 2011).

\section{Discussion}

Attaining fiscal solvency is admittedly a big challenge to most local governments globally (Lessman, 2012; Talvi \& Végh, 2005). The complication is rooted in the entity's capacity to sustainably operate functioning budgets and providing quality and satisfactory public goods and services to local communities. Budgeted revenue amounts must be 
collected and spent effectively. Public goods and services offered must be of the type that suitably fit community social and economic well-being (Arzaghi \& Henderson, 2005).

Over the years, the complexity surrounding fiscal solvency has rendered policy, practice, and research inconclusive on its origin and the way forward. Previous studies claim that the digital financial inclusion-regulation blend is the most important solution to understand the extent to which digital financial inclusion-regulation traits contribute to violations of fiscal solvency behavior (Morawczynski, 2009; Otenyo \& Lind, 2004; Yakub, Bello \& Adenuga, 2013).

In this study, transactional platform, retail agents, and devices; attributes of digital financial inclusion (Olayinka, 2015; Salvador, Sherry \& Urrutia, 2005), are examined as predictors of fiscal solvency. First, we hypothesized a transactional platform to predict fiscal solvency. The results did not support that hypothesis (Hypothesis 1).

Secondly, it was projected that retail agents' activities predict fiscal solvency. The results supported the hypothesis (Hypothesis 2). Moreover, thirdly, we proposed that the trait device predicts fiscal solvency. This proposition was supported by the results (Hypothesis 3). Fourthly, we hypothesized regulation mediates the digital financial inclusion-fiscal solvency relationship. Results also supported that hypothesis (Hypothesis 4). The hypotheses and their findings are discussed in the following sections.

\section{Transactional platform and fiscal solvency}

In line with Hypothesis 1, this research shows that changes in the transactional platform attribute of digital financial inclusion cannot change the local government's fiscal solvency. Importantly, we controlled for participant biographical characteristics such as gender, age, educational level, and tenure to influence fiscal solvency (Lessman, 2012; Talvi \& Végh, 2005). However, the transactional platform-fiscal solvency effect remains the same. Thus, we propose that a transactional platform may not, after all, be an antecedent of locality fiscal solvency.

Much as the platform enhances the e-financial transfers and leads to ultimate improvements in societal incomes, most of the population is not connected to that facility (Morawczynski, 2009; Phillips \& Ilcan, 2007). Therefore, this implies that e-platform may directly influence entity revenue generation through tax increments but little impact on service-level benefits.

For instance, in several communities of Uganda's post-conflict regions, schools are distantly located, health units lack relevant drugs, roads are impassable, and tap water is simply not available (Reinikka \& Svensson, 2006). The over two-decade existence of digital financial systems in the regions has failed to help local authorities bring about any meaningful improvement in service delivery. Unfortunately, the local authorities neither have the technical capacity nor the mandate to initiate any platform structure changes. Local entities are mere recipients (Reinikka \& Svensson, 2006; Talvi \& Végh, 2005). Besides, the few studies conducted on digital financial inclusion-fiscal solvency formation in other African-based local governments (Olayinka, 2015; Yakub, Bello \& Adenuga, 2013) associate most platforms with very unpredictable and potentially unreliable connections, which often disorganize customer financial plans.

In sum, the transactional platform-fiscal solvency configuration suggested at the introduction of Hypothesis 1 is contradicted by the findings based on the previous platform-fiscal solvency limitations. The challenge may constitute not only a promising direction for future research but also interventions. The transactional platform is purportedly that high-tech structure meant to provide a robust foundation for all connections. Salvador et al. (2005) suggest that local authorities should intervene by liaising with e-service providers to tailor their mechanical structures to local 
environments for the platform to benefit African-based jurisdictions. It will somehow solve system connection failures (Madon, 2005; Salvador, Sherry \& Urrutia, 2005).

\section{Retail agents and fiscal solvency}

As expected, affirmative retail agent activities may generate similarly constructive developments in the local entity fiscal solvency drive. The finding which supports Hypothesis 2 is in line with previous empirical evidence (Gilbert, 2005; Phillips \& Ilcan, 2007). The agents link the transactional platform to the customer and vice versa, making the digital financial inclusion dream almost attain reality.

In some jurisdictions, say, Tigo Family Care insurance (Ghana), M-Pesa (Kenya), and The FirstMonie (Nigeria), retail agents work hand-in-hand with the digital service providers to sensitize customers on how to utilize the facilities. It makes customers appreciate and embrace the services (Morawczynski, 2009; Olayinka, 2015).

From the fiscal solvency perspective, the role of e-financial services retail agents significantly boosts local revenue collections. It is so as most authorities subject both the enhanced customer businesses and the agents to various forms of local charges, fees, and taxes (Phillips \& Ilcan, 2007; Schneider \& Enste, 2000).

However, it must be stressed that it would be unfair to be adamant on the full certainty surrounding the retail agents' function in the digital financial inclusion-fiscal solvency equation. Several studies (e.g., Gilbert, 2005; Madon, 2005; Salvador, Sherry \& Urrutia, 2005) attribute most failures in the relationship to questionable professional and technical competencies and personal conduct of the numberless retail agents.

For instance, Salvador et al. (2005) noted that most agents find themselves in the digital service business as a mere form of temporary employment and a way of making money for survival. They lack proper training and hold no intentions of specializing in that field. It partially explains why the agents are often less-mindful of customer care and customer service, especially when dealing with the largely illiterate communities (Madon, 2005; Salvador, Sherry \& Urrutia, 2005).

Thus, our Hypothesis 2 and its findings propose that the role played by retail agents in the digital financial inclusion-fiscal solvency relationship is not the only antecedent but, to a very large extent, it is also consequential. Besides, the actor-network theory asserts that if no proper and prompt action is taken to mitigate its negative influence, agents' actions may not only delay but can completely frustrate the realization of the efinancial inclusion dream (Green, Hull, McMeekin \& Walsh, 1999; Hanseth, Monteiro \& Hatling, 1996). It will have very serious repercussions on fiscal solvency in local jurisdictional entities.

Phillips \& Ilcan (2007) and Yakub, Bello \& Adenuga (2013) suggest that national and local authorities should strengthen related regulations and emphasize customer sensitization. All retail agents must be trained on how to manage financial resources and relate to community-based populations. Moreover, the local authorities must appreciate the retail contribution agents make to their budgetary structures and revenue coffers in particular. Thus, through the agents, authorities can seek technical advice from digital financial service providers on how digital financing can support service delivery (Madon, 2005; Olayinka, 2015; Yakub, Bello \& Adenuga, 2013).

\section{Device and fiscal solvency}

The current study predicted that digital financial inclusion's device component plays a positive role in local entity fiscal solvency endeavors (Hypothesis 3). In line with empirical and theoretical propositions (Gilbert, 2005; Green, Hull, McMeekin \& Walsh, 1999; Hanseth, Monteiro \& Hatling, 1996; Salvador et al., 2005), the hypothesis secures substantial support from the study that actually this is the case. 
In local community settings, northern Uganda's post-war societies inclusive, efficient, and easy-to-operate digital devices play a pivotal role in stimulating digital financial inclusion connectivity. It has been especially empowered by the presence of numerous network masts erected by service providers almost everywhere in the localities (Morawczynski, 2009; Olayinka, 2015).

Another quite interesting pattern in the digital device results replicates findings in the works of (Madon, 2005; Phillips \& Ilcan, 2007; Schneider \& Enste, 2000). Mandatory registration of user-devices attracts mixed reactions from mobile financial service consumers. In northern Uganda, device registration is often interpreted as a strategic move by authorities to infringe customer secrecy rights. It exposes customer incomes, spending habits, and partisan political stand. Moreover, it could be a deliberate move to victimize them regarding the quality of public goods and services offered (Olayinka, 2015; Phillips \& Ilcan, 2007).

However, where such fears are moderate, connectivity benefits override costs, especially concerning fiscal solvency. Thus, Schneider \& Enste (2000) recommend that responsible communication commissions, institute regulations that emphasize importing durable and user-friendly devices that enhance digital financial inclusion efficiency. Local entity revenue and budgetary incentives stand to benefit in the long-run (Madon, 2005; Schneider \& Enste, 2000).

\section{Digital financial inclusion-regulation-fiscal solvency}

Regulation seems to dominate the digital financial inclusion-local entity fiscal solvency debate, especially in Sub-Saharan Africa (Morawczynski, 2009; Olayinka, 2015; Yakub, Bello \& Adenuga, 2013). In this research, it was proposed, Hypothesis 4, and later found supported by data that regulation is a possible mediator in the digital financial inclusion-fiscal solvency make-up. That is to say, existing fiscal laws and statutes coupled with those governing digital financial activities, have a serious bearing on fiscal solvency's financial inclusion drive and achievement.

Morawczynski (2009) argues that the mechanical e-financial inclusion vision nurtured by most jurisdictions in Africa are not only difficult to attain but also extensively hampered by unrealistic regulation governing most local entity beneficiaries. Notably, only a handful of national constitutions and their outgrowth sub-national entity laws capture digital financial inclusion's volatile operational requirements. It often culminates in high transaction platform-retail agent-device abuses with impunity, especially from the local government fiscal solvency context (Morawczynski, 2009; Olayinka, 2015).

\section{CONCLUSION AND RECOMMENDATIONS}

The current research advances empirical, theoretical, and practical understanding of how digital financial inclusion and regulation influence fiscal solvency in local government in three ways. Previous studies focused mainly on attaining locality fiscal solvency through conventional local revenue collections, grants, and donor support (Arzaghi \& Henderson, 2005; Sepulveda \& Martinez-Vazquez, 2011). Today, grants and donor aid may not necessarily be a direct function of financial digitalization from the local society setting.

Incomes of local communities are currently severely subjected to the dynamics of electronic money transfers and communication. Ultimately, both local incomes and related business activities have grown (Olayinka, 2015; Yakub, Bello \& Adenuga, 2013). This study provides the implication, for future empirical deliberations, that admittedly the conventional local revenue set-up has consequently expanded and thus requires relevant adjustments in the budgetary systems. 
Furthermore, this perspective advances the actor-network theoretical advocacy (Hanseth, Monteiro \& Hatling, 1996) for local authorities to embrace digital financial inclusion in their agenda to realize the fiscal solvency goal. However, this call has received little policy, practice, and empirical attention in the developing countries, possibly due to its focus on fiscal efficiency in advanced economies (Phillips \& Ilcan, 2007).

The findings of this investigation suggest that there is a need for an all-embracing theory that captures the financial digitalization-fiscal efficiency-local community linkages with a particular focus on the developing world.

The research was conducted to assess how digital financial inclusion attributes; transactional platform, retail agents, and devices initiate change in locality fiscal solvency. Suitable scales (Baruch \& Holton, 2008; Cohen et al., 2003) were developed and validated to quantify participant perceptions of various domains systematically. Therefore, the study lays a strong footing for new theoretical and quantitative methodological advancements for future digital financial inclusion-fiscal solvency investigations. This contribution is significant given that the previous, largely qualitative studies (Morawczynski, 2009; Yakub, Bello \& Adenuga, 2013), overlooked refined measurements that could tap deep into the fiscal solvency formation.

Third, this study is also relevant for practice in local government. Its findings suggest embracing digital financial inclusion in local revenue mobilization and management revamps budgeting and service delivery. Authorities need to formulate budgets considerate of e-financial inclusion and create mechanisms that promote linkages with electronic financial services providers (Green, Hull, McMeekin \& Walsh, 1999; Hanseth, Monteiro \& Hatling, 1996). Local establishments should also advocate for enforceable regulation that is particularly tailored to their local fiscal solvency realities and flexible enough to accommodate the digital financial inclusion dynamics.

Despite the above noted contributions of the study to the knowledge body, several potential limitations need to be appreciated. First, the research focused on the transactional platform, retail agents, and devices as potential predictors of fiscal solvency in local government. Although the three dimensions are the most renowned influential attributes of digital financial inclusion, rapid developments in the electronic financial field (Hanseth, Monteiro \& Hatling, 1996; Phillips \& Ilcan, 2007) suggest that others are not particularly mainstream.

Failure to exploit such dimensions may have been a setback to fully exploring fiscal solvency in local entities. For instance, future studies need to investigate community reactions to the widespread construction of communication masts, especially in residential neighborhoods. The waves such masts transmit may have serious repercussions on the people's health in the long-run (Phillips \& Ilcan, 2007).

Second, the study largely employed self-report data to validate its scales. A crosssectional design was used while construct and discriminant validity were the main focus. That set-up was adopted with a view of generating a theoretically well-defined and accurate instrument capable of collecting reliable data. However, given that self-report data are not very comprehensive (Baruch \& Holton, 2008; Creswell, 2003), more value is feasible in future research that exploits other research designs. For instance, longitudinal design, self-other ratings, objective, and other behavioral outcome approaches are good candidates (Cohen et al., 2003).

Finally, this was a simulation investigation, and its models may likely have been over-simplified (Barrett, 2007; Cheung \& Lau, 2008). Interpreting over-simplified models is often associated with oversight to critical inter-variable relationships. Future 
studies can avoid over-simplification by adopting models with suitable variables for better theoretical composition and enhanced methodological posture (Bollen, 1990; Cheung \& Lau, 2008).

\section{REFERENCES}

Alesina, A., Baqir, R. \& Easterly, W. (1999). Public Goods and Ethnic Divisions. Quarterly Journal of Economics, 114(4), 1243-84.

Arzaghi, M. \& Henderson, J. (2005). Why countries are fiscally decentralizing. Journal of Public Economics, 89, 1157-1189.

Barrett, P. (2007). Structural Equation modeling: Adjudging model fit. Personality and individual Differences, 42(5), 815-824.

Baruch, Y. \& Holton, B.C. (2008). Survey response rate levels and trends in organizational Research. Human Relations, 61(8), 1139-1160.

Bollen, K. A. (1990). Overall fit in covariance structure models: Two types of sample size Effects. Psychological Bulletin, 107(2), 256-259.

Cheung, G.W. \& Lau, R.S. (2008). Testing mediation and suppression effects of latent variables: Bootstrapping with structural equation models. Organizational Research Methods, 11, 296-325.

Cohen, J., Cohen, P., West, S.G. \& Aiken, L.S. (2003). Applied Multiple Regression/Correlation Analysis for Behavioral Sciences. Mahwah, NJ: Lawrence Erlbaum Associates Publishers.

Creswell, J. W. (2003). Research design: Qualitative, quantitative, and mixed methods Approaches (2nd ed.). Thousand Oaks, CA: Sage.

de Mello, L.R. Jr. (2000). Fiscal Decentralization and Intergovernmental Fiscal Relations: A Cross-Country Analysis. World Development, 28(2), 365-380.

Gauthier, B. (2001). Productivity and Exports, in Reinikka, R. \& Collier, P. (eds.), Uganda's Recovery: The Role of Farms, Firms, and Government. World Bank Regional and Sectoral Studies, Washington, D.C. World Bank.

Gilbert, E. (2005). Common cents: Situating money in time and place. Economy and Society, 34(3), 357-388.

Green, K., Hull, R., McMeekin, A. \& Walsh, V. (1999). The construction of the technoeconomic: networks vs paradigms. Research Policy, 28, 777-792.

Hanseth, O., Monteiro, E. \& Hatling, M. (1996). Developing information infrastructure: The tension between standardization and flexibility. Science, Technology and Human Values, 21(4), 407-426.

Kenny, D. (2008). Reflections on mediation. Organizational Research Methods, 11(2), 353-358.

King, D. N. (1984). Fiscal Tiers: The Economics of Multi-Level Government, London: Allen \& Unwin.

Lessman, C. (2012). Regional inequality and decentralization: An empirical analysis. Environment and Planning A, 44(6), 1363-1388.

Madon, S. (2005). Evaluating the developmental impact of e-governance initiatives: An exploratory framework. Electronic Journal of Information Systems in Developing Countries, 20(5), 1-13.

Morawczynski, O. (2009). Exploring the usage and impact of transformational mobile financial services: The case of M-PESA in Kenya. Journal of Eastern African Studies, 3(3), 509-516.

Musgrave, R.A. \& Musgrave, P. B. (1980). Public Finance in Theory and Practice, New York: McGraw-Hill. 
Oates, W. E. (1972). Fiscal Federalism, New York: Harcourt Brace Jovanovich.

Olayinka, D-W. (2015). The path to digital financial inclusion in Nigeria: Experiences from FirstMonie. Journal of Payments Strategy and Systems, 9(4), 256-273.

Otenyo, E.E. \& Lind, N.S. (2004). Faces and phases of transparency reform in local government. International Journal of Public Administration, 27(5), 287-307.

Phillips, L. \& Ilcan, S. (2007). Responsible expertise: Governing the uncertain subjects of Biotechnology. Critique of Anthropology, 27(1), 103-126.

Preacher, K.J. \& Kelley, K. (2011). Effect size measures for mediation models: Quantitative strategies for communicating indirect effects. Psychological Methods, $16,93-115$.

Prud'homme, R. (1995). The Dangers of Decentralization. World Bank Research Observer, 10(2), 201-220.

Reinnikka, R. \& Svensson, J. (2004). Local capture: Evidence from a central government transfers program in Uganda. Quarterly Journal of Economics, 119, 679-706.

---- . (2006). Using micro-surveys to measure and explain corruption. World Development, 34(2), 359-370.

Salvador, T., Sherry, J.W. \& Urrutia, A. E. (2005). Less cyber, more café; enhancing existing small businesses across the digital divide with ICTs. Information Technology for Development, 11(1), 77-95.

Schneider, F. \& Enste, D. (2000). Shadow economies: Size, causes and consequences. Journal of Economic Literature, 38, 77-114.

Sepulveda, C. \& Martinez-Vazquez, J. 2011. The consequences of fiscal decentralization on poverty and income inequality. Environment and Planning, 29, 321-343.

Shrout, P. E. \& Bolger, N. (2002). Mediation in experimental and non-experimental studies: New procedures and recommendations. Psychological Methods, 7(4), 422445.

Talvi, E. \& Végh, C. (2005). Tax Base Variability and Pro-cyclical Fiscal Policy in Developing Countries. Journal of Development Economics, 78(1), 156-190.

Thornton, J. (2007). Fiscal Decentralization and Growth Reconsidered. Journal of Urban Economics, 61, 64-70.

Yakub, J.O., Bello, H.T. \& Adenuga, I.A. (2013). Mobile money services in Nigeria: An inquiry of existing models. International Journal of Economics and Management Sciences, 7, 94-105.

(C) 2021 by the authors. Licensee JPPD, Indonesia. This article is an open-access article distributed under the terms and conditions of the Creative Commons Attribution (CC BY) license (http://creativecommons.org/licenses/by/4.0/). 